\title{
CLINICOPATHOLOGICAL STUDY OF BENIGN LESIONS OF LARYNX
}

\author{
Anand Navnath Tuljapure1, Sunil Deshmukh², Suresh Kumar Tarachand Jain ${ }^{3}$, Vasant Pawar
}

${ }_{1}^{1}$ Assistant Professor, Department of ENT, Government Medical College, Aurangabad, Maharashtra.

2 Professor and HOD, Department of ENT and Head and Neck Surgery, Government Cancer Hospital, Aurangabad, Maharashtra.

3 Professor and HOD, Department of ENT, Government Medical College, Aurangabad, Maharashtra.

${ }^{4}$ Associate Professor, Department of ENT, Government Medical College, Aurangabad, Maharashtra.

ABSTRACT

\section{BACKGROUND}

Benign laryngeal lesions are a spectrum of laryngeal diseases where symptoms vary from discomfort in throat, pain in throat, change of voice to stridor. Prompt diagnosis, intervention and speech therapy will reverse the conditions in certain laryngeal lesions.

Aims and Objectives- A clinical study was undertaken to analyse the age, sex distribution and symptomatology, sites of involvement and the prognosis of the common types of benign lesions of larynx.

\section{MATERIALS AND METHODS}

A total of 40 patients with benign laryngeal lesions were included based on symptomatology such as hoarseness of voice, foreign body sensation, throat pain, neck mass and cough with positive clinical findings on indirect laryngoscopy and neck examination. The patients ranged from 5 - 65 years. All non-operative cases and malignant cases were excluded. Diagnostic haematological and radiological investigations and therapeutic microlaryngoscopic procedures were employed.

Study Design- A two years descriptive type of study from November 2013 to November 2015.

Setting- A tertiary referral hospital.

\section{RESULTS}

A male preponderance with M: F ratio of 3: 2 was observed. Majority of the patients were in the 31 - 40 years' age group. Vocal polyps were the commonest type of lesion. In our study, hoarseness of voice, cough, foreign body sensation and throat pain proved to be the commonest symptoms.

\section{CONCLUSION}

Microlaryngeal surgery and voice rest offer a cost effective, useful and safe method.

\section{KEY WORDS}

Larynx, Hoarseness, Microlaryngoscopic Surgery.

HOW TO CITE THIS ARTICLE: Tuljapure AN, Deshmukh S, Jain SKT, et al. Clinicopathological study of benign lesions of larynx. J. Evolution Med. Dent. Sci. 2018;7(20):2468-2474, DOI: 10.14260/jemds/2018/556

\section{BACKGROUND}

"Speech is civilisation itself. The word, even the most contradictory word preserves the contact. It is silence that isolates."

Thomas Mann ${ }^{1}$ - Voice is the natural medium well adapted to communicate emotional contact, whereas speech is a cultural medium that is suitable to convey intellectual contact. $^{2}$

Human voice serves a number of communicative functions. Some are associated with spoken language and others are unrelated to speech and language, voice alone can communicate several non-verbal messages. ${ }^{3}$

Hoarseness of voice is one of the commonest symptoms in otolaryngological practice and is invariably the earlier manifestation of a large variety of conditions, directly or indirectly affecting the voice apparatus.

'Financial or Other Competing Interest': None.

Submission 29-03-2018, Peer Review 01-05-2018,

Acceptance 07-05-2018, Published 14-05-2018.

Corresponding Author:

Dr. Anand Navnath Tuljapure,

Anand Nivas, Near Swami Samarth Mandir,

Shahu Nagar, Osmanbad-413501,

Maharashtra, India.

E-mail: anand05tuljapure@gmail.com

DOI: $10.14260 /$ jemds $/ 2018 / 556$
Hoarseness is a common complaint in today's fast faced, high stressed life. ${ }^{4}$ In India and other developing countries, the prevailing lower economic status, poorer nutrition, poorer general health of population, different food habits, vocal habits, smoking and drinking habits, unhealthy environment and different social customs definitely influence the incidence of hoarseness.

Benign lesions of the larynx constitute an interesting array of lesions.

These lesions are defined as an abnormal mass of tissue in the larynx, the growth of which exceeds and is uncoordinated with that of the normal tissue and persists in the same excessive manner after cessation of stimuli which evoke the change. ${ }^{5}$

Benign lesions of the larynx generally produce a common symptomatology known as dysphonia.

The symptoms which they produce by interference with the routine functioning of the vocal cord mechanism and respiratory tract along with the necessity to distinguish them from malignant laryngeal lesions, makes these lesions important to a laryngologist. 


\section{Aims and Objectives}

The Aim of this Study was-

1. To analyse the demographics such as (Age, Sex, Occupation) of benign lesions of larynx over a period of two years.

2. To study symptomatology of benign lesions of larynx.

3. To study anatomy and site of involvement of benign lesions of larynx.

4. To study prognosis of the most frequent benign lesions of the larynx along with follow-up of the patients up to 6 months.

\section{MATERIALS AND METHODS}

This was a descriptive type of study carried out at tertiary health care centre. This study consisted of 40 patients from November 2013 to November 2015. They all had positive clinical findings on indirect laryngoscopy, confirmation by videolaryngoscopy and neck examination.

Investigations included were routine blood investigations, urine microscopy, sputum for acid fast bacillus (AFB), radiological investigations [x-ray of paranasal sinuses, $\mathrm{x}$-ray of chest (postero-anterior view), plain x-ray neck- lateral view], direct laryngeal endoscopy, indirect laryngoscopy and videolaryngoscopy were done. CT scan of neck was done in cases for exclusion of malignancy.

\section{Statistical Analysis}

Statistical analysis was done by descriptive statistics as mean, $\mathrm{SD}$, percentage etc. Data were presented in Tables and Graphs. ' $\mathrm{Z}$ ' test of difference between two proportions was applied at $5 \%(p, 0.05)$ and $1 \%(p, 0.01)$ level of significance. Also, Chi-square test was applied to find out association between two variables. Statistical software SPSS 20.0 (USA) was used. The findings were discussed in the light of findings in other similar studies conducted elsewhere based on the objective of study in the foregoing chapters.

\section{Inclusion Criteria}

- $\quad$ All patients attending ENT OPD with hoarseness/ change of voice in age group of 5 - 65 years.

- Irritation in throat.

- Difficulty in breathing.

- Foreign body sensation in the throat.

- Painful voice production.

- Vocal fatigue (Asthenia).

\section{Exclusion Criteria}

- Patients with clinical diagnosis of malignancy of larynx.

- Patients with speech defect due to central nervous system lesion.

- $\quad$ Patients with oral, nasal and pharyngeal pathology.

- $\quad$ Patients with puberty related voice change.

\section{RESULTS}

A total of 40 cases were studied during study period. A total of 54,700 cases attended ENT OPD during study period out of these 40 cases presented with hoarseness of voice. Thus, the incidence is $0.073 \%$ of all cases.

\begin{tabular}{|c|c|c|c|c|c|c|}
\hline \multirow{2}{*}{$\begin{array}{c}\text { Age in } \\
\text { Years }\end{array}$} & \multicolumn{2}{|c|}{ Male } & \multicolumn{2}{c|}{ Female } & \multicolumn{2}{c|}{ Total } \\
\cline { 2 - 7 } & No. & $\mathbf{\%}$ & No. & $\mathbf{\%}$ & No. & $\mathbf{\%}$ \\
\hline $5-10$ yrs. & 0 & 0 & 0 & 0 & 0 & 0 \\
\hline $11-20$ & 2 & 5 & 1 & 2.5 & 3 & 7.5 \\
\hline $21-30$ & 6 & 15 & 3 & 7.5 & 9 & 22.5 \\
\hline $31-40$ & 11 & 27.5 & 5 & 12.5 & 16 & 40 \\
\hline $41-50$ & 4 & 10 & 2 & 5 & 6 & 15 \\
\hline $51-60$ & 3 & 7.5 & 2 & 5 & 5 & 12.5 \\
\hline $61-65$ & 1 & 2.5 & 0 & 0 & 1 & 2.5 \\
\hline Total & $\mathbf{2 7}$ & $\mathbf{6 7 . 5}$ & $\mathbf{1 3}$ & $\mathbf{3 2 . 5}$ & $\mathbf{4 0}$ & $\mathbf{1 0 0}$ \\
\hline \multirow{2}{*}{ Mean } & $\begin{array}{c}3.8571 \pm \\
3.716\end{array}$ & $\begin{array}{c}1.8571 \pm \\
1.7728\end{array}$ & & $\begin{array}{c}5.71 \pm \\
5.46\end{array}$ & \\
\hline \multicolumn{3}{|c|}{ Table 1. Age and Sex Distribution (n= 40) } \\
\hline
\end{tabular}

40 cases of benign laryngeal lesions were studied during study period. Maximum number, i.e. 16 cases (40\%) belonged to 31 - 40 years of age group and minimum number i.e. 1 case $(2.5 \%)$ belonged to 61 - 65 years of age group. 27 cases $(67.5 \%)$ were males and 13 cases $(32.5 \%)$ were females. Youngest patient was of 11 years old and eldest patient was of 62 years of age.

\begin{tabular}{|c|c|c|c|c|c|c|c|}
\hline Symptoms & $0-6$ months & $6-12$ & $12-18$ & $18-24$ & $>24$ & $\begin{array}{l}\text { Total } \\
\text { Patients }\end{array}$ & $\begin{array}{l}\text { Percentage } \\
\%\end{array}$ \\
\hline $\begin{array}{l}\text { Hoarseness/chang } \\
\text { e of voice }\end{array}$ & 20 & 11 & 4 & 5 & 1 & 40 & 100 \\
\hline Vocal Fatigue & 14 & 7 & 2 & 2 & 1 & 26 & 65 \\
\hline $\begin{array}{l}\text { Painful voice } \\
\text { Production }\end{array}$ & 8 & 4 & 1 & 0 & 0 & 13 & 32.5 \\
\hline $\begin{array}{l}\text { Irritation in } \\
\text { Throat }\end{array}$ & 6 & 4 & 0 & 2 & 0 & 12 & 30 \\
\hline $\begin{array}{l}\text { Difficulty in } \\
\text { Swallowing }\end{array}$ & 6 & 4 & 1 & 0 & 0 & 11 & 27.5 \\
\hline $\begin{array}{l}\text { Foreign body } \\
\text { Sensation }\end{array}$ & 4 & 1 & 1 & 0 & 0 & 6 & 15 \\
\hline $\begin{array}{l}\text { Difficulty in } \\
\text { Breathing }\end{array}$ & 2 & 0 & 0 & 0 & 0 & 2 & 5 \\
\hline
\end{tabular}

Table 2. Chief Complaints and Duration in Months $(n=40)$

In our study, change in voice/ hoarseness of voice was the main complaint of 40 cases (100\%). Duration of change in voice was mainly 0 - 6 months in 20 cases, $6-12$ months in 11 cases, 12 - 18 months in 4 cases, 18 - 24 months in 5 cases, more than 24 months in 1 case.

Other complaints were vocal fatigue in 26 cases (65\%), painful voice production in $13(32.5 \%)$ cases, irritation in throat 12 cases (30\%), difficulty in swallowing in 11 (27.5\%) cases, foreign body sensation in 6 cases $(15 \%)$ and difficulty in breathing in 2 cases (5\%) were present.

\begin{tabular}{|c|c|c|c|c|c|c|}
\hline Occupation & & Male & & Female & & Total \\
\hline & No & $\%$ & No. & $\%$ & No & $\%$ \\
\hline Farmer & 3 & 7.5 & 0 & 0 & 3 & 7.5 \\
\hline Labourer & 3 & 7.5 & 2 & 5 & 5 & 12.5 \\
\hline House wife & 0 & 0 & 7 & 17.5 & 7 & 17.5 \\
\hline Student & 2 & 5 & 1 & 2.5 & 3 & 7.5 \\
\hline Teacher & 5 & 12.5 & 2 & 5 & 7 & 17.5 \\
\hline Watchman & 1 & 2.5 & 0 & 0 & 1 & 2.5 \\
\hline Nurse & 0 & 0 & 1 & 2.5 & 1 & 2.5 \\
\hline Singer & 3 & 7.5 & 0 & 0 & 3 & 7.5 \\
\hline Driver & 4 & 10 & 0 & 0 & 4 & 10 \\
\hline Waiter & 2 & 5 & 0 & 0 & 2 & 5 \\
\hline Sweeper & 1 & 2.5 & 0 & 0 & 1 & 2.5 \\
\hline Imam & 2 & 5 & 0 & 0 & 2 & 5 \\
\hline Engineer & 1 & 2.5 & 0 & 0 & 1 & 2.5 \\
\hline Total & 27 & 67.5 & 13 & 32.5 & 40 & 100 \\
\hline
\end{tabular}

Table 3. Occupation $(n=40)$ 
By applying ' $\mathrm{Z}$ ' test of difference between two proportions, the proportion of occupation teachers i.e. 5 cases $(10 \%$ each) in males and housewives i.e. 7 cases $(17.5 \%)$ in females was significantly higher as compared to other occupations $(\mathrm{p}<0.01)$.

\begin{tabular}{|c|c|c|c|c|c|c|}
\hline $\begin{array}{c}\text { Socioeconomic } \\
\text { status }\end{array}$ & No & $\%$ & No. & $\%$ & No & $\%$ \\
\hline Upper & 1 & 2.5 & 0 & 0 & 1 & 2.5 \\
\hline Upper Middle & 11 & 27.5 & 4 & 10 & 15 & 37.5 \\
\hline Middle & 8 & 20 & 5 & 12.5 & 13 & 32.5 \\
\hline Lower Middle & 3 & 7.5 & 1 & 2.5 & 4 & 10 \\
\hline Lower & 4 & 10 & 3 & 7.5 & 7 & 17.5 \\
\hline Total & 27 & 67.5 & 13 & 32.5 & 40 & 100 \\
\hline
\end{tabular}

Table 4. Socioeconomic Status $(n=40)$

The correlation was not significant $(\mathrm{p}=0.873$, Correlation Coefficient $=0.10$ ).

By applying ' $\mathrm{Z}$ ' test of difference between two proportions, the proportion of socioeconomic status of upper middle class in males i.e. 11 cases (27.5\%) and middle class in females i.e. 5 cases $(12.5 \%)$ was significantly higher in benign laryngeal lesions $(\mathrm{p}<0.01)$.

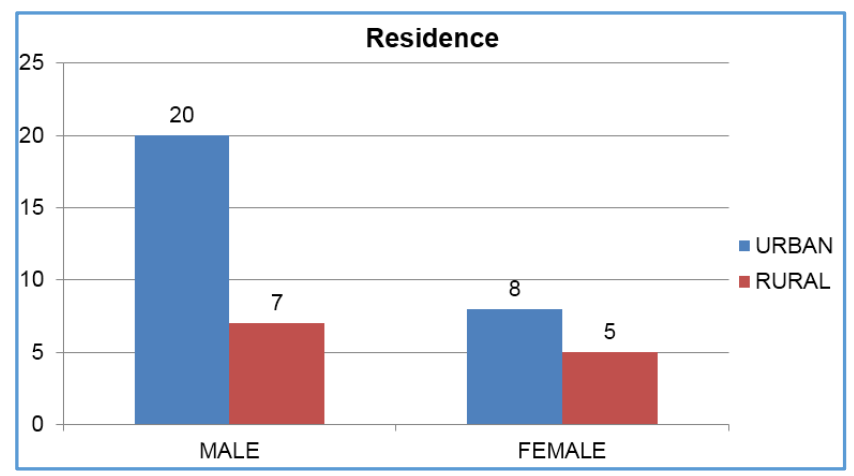

Table 5. Residence $(n=40)$

The correlation was not significant $(\mathrm{p}=1$, Correlation Coefficient $=1.0$ )

Maximum cases i.e. 27 cases $(67.5 \%)$ were from urban area and minimum cases i.e. 13 cases $(32.5 \%)$ were from rural area.

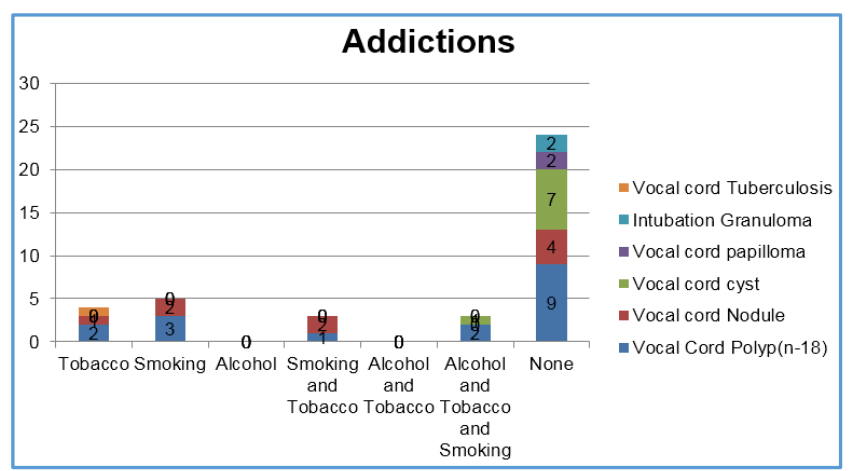

Table 6. Habits and Addictions

In our study among benign masses of larynx, tobacco chewing was found to be the commonest addiction followed by alcohol and smoking. Out of 18 cases of vocal fold polyps, 2 cases had addiction to tobacco, 3 had addictions to smoking, 1 had addiction of both smoking and alcohol, 2 had addictions to tobacco, smoking and alcohol and 9 cases had no addictions. No addiction group turned to be the commonest in vocal fold nodules, vocal cord cyst, intubation, granuloma as well as laryngeal papilloma.

No addiction cases mostly are professional voice users viz. teachers, singers and drivers and non-professional users were housewives. Vocal misuse and vocal abuse is more common among all these cases.

\begin{tabular}{|c|c|c|c|c|c|c|}
\hline \multirow{2}{*}{ IDL } & \multicolumn{2}{|c|}{ Male } & \multicolumn{2}{c|}{ Female } & $\begin{array}{c}\text { No. of } \\
\text { Cases } \\
\text { (n= 40) }\end{array}$ & \% \\
\cline { 2 - 7 } & No. & $\mathbf{\%}$ & No. & $\mathbf{\%}$ & 45 \\
\hline Vocal cord polyp & 11 & 27.5 & 7 & 17.5 & 18 & 45 \\
\hline Vocal cord nodule & 8 & 20 & 1 & 2.5 & 9 & 22.5 \\
\hline Vocal cord cyst & 6 & 15 & 2 & 5 & 8 & 20 \\
\hline $\begin{array}{c}\text { Laryngeal } \\
\text { papilloma }\end{array}$ & 0 & 0 & 2 & 5 & 2 & 5 \\
\hline $\begin{array}{c}\text { Intubation } \\
\text { granuloma }\end{array}$ & 1 & 2.5 & 1 & 2.5 & 2 & 5 \\
\hline $\begin{array}{c}\text { Laryngeal TB } \\
\text { granuloma }\end{array}$ & 1 & 2.5 & 0 & 0 & 1 & 2.5 \\
\hline Total & $\mathbf{2 7}$ & $\mathbf{6 7 . 5}$ & $\mathbf{1 3}$ & $\mathbf{3 2 . 5}$ & $\mathbf{4 0}$ & $\mathbf{1 0 0}$ \\
\hline
\end{tabular}

Table 7. Clinical and Laryngoscopic (IDL) Examination $(n=40)$

Out of 14 cases subjected to IDL scopy 18 (45\%) were vocal fold polyps, 9 (22.5\%) were vocal fold nodules, 8 (20\%) were vocal cord cyst, laryngeal papilloma 2 (5\%), intubation granuloma $2(5 \%)$ and laryngeal tubercular granuloma 1 (2.5\%). All these cases underwent videoendoscopic laryngeal examination for confirmation. The correlation was not significant $(\mathrm{p}=0.667$, Correlation Coefficient $=0.50)$.

In our study, commonest site of origin of lesions was from true vocal cords. Nearly, $100 \%$ of lesions were from true vocal cords. In our study, right true vocal cord involvement in 19 cases $(47.5 \%)$ is more than left true vocal cord 9 cases (22.5\%).

Both true vocal cords were involved in 12 cases (30\%).

\section{SITE OF INVOLVEMENT ON VOCAL CORDS}

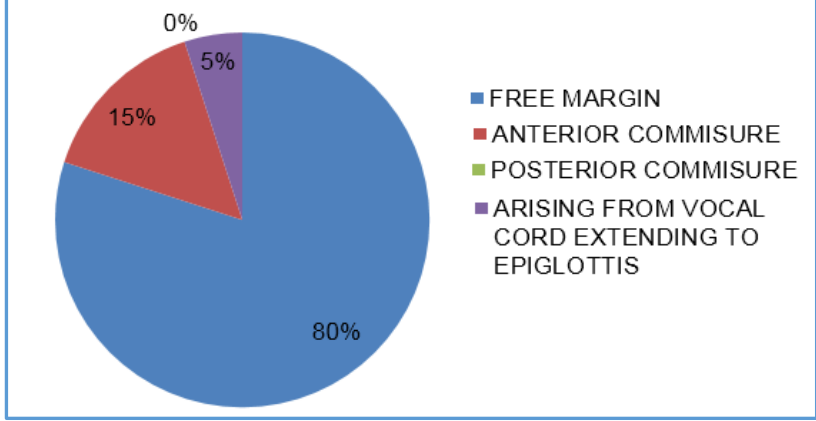

Table 8. Site of Involvement on Vocal Cords $(n=40)$

The correlation was highly significant correlation between the site on vocal cords. That is occurrence rate was higher on free margins of true vocal cord $(p=0.01$, correlation coefficient $=0.00$ ).

In our study, free margins of true vocal cords were commonly involved, i.e. 32 cases (80\%). 


\begin{tabular}{|c|c|c|c|c|c|}
\hline $\begin{array}{c}\text { Clinical } \\
\text { Diagnosis }\end{array}$ & $\begin{array}{c}\text { Total } \\
\text { No. }\end{array}$ & $\%$ & Histopathology & No. & $\%$ \\
\hline $\begin{array}{l}\text { Vocal cord } \\
\text { polyp }\end{array}$ & 18 & 45 & Angiomatous polyp & 10 & 25 \\
\hline & & & Inflammatory polyp & 8 & 20 \\
\hline $\begin{array}{l}\text { Vocal cord } \\
\text { nodule }\end{array}$ & 9 & 22.5 & Vocal cord nodule & 9 & 22.5 \\
\hline $\begin{array}{l}\text { Vocal cord } \\
\text { cyst }\end{array}$ & 8 & 20 & Vocal cord cyst & 8 & 20 \\
\hline $\begin{array}{l}\text { Laryngeal } \\
\text { papilloma }\end{array}$ & 2 & 5 & Squamous papilloma & 2 & 5 \\
\hline $\begin{array}{l}\text { Intubation } \\
\text { granuloma }\end{array}$ & 2 & 5 & $\begin{array}{c}\text { Infected granulation } \\
\text { tissue }\end{array}$ & 2 & 5 \\
\hline $\begin{array}{l}\text { Laryngeal } \\
\text { TB } \\
\text { granuloma }\end{array}$ & 1 & 2.5 & TB Granuloma & 1 & 2.5 \\
\hline Total & 40 & 100 & & 40 & 100 \\
\hline
\end{tabular}

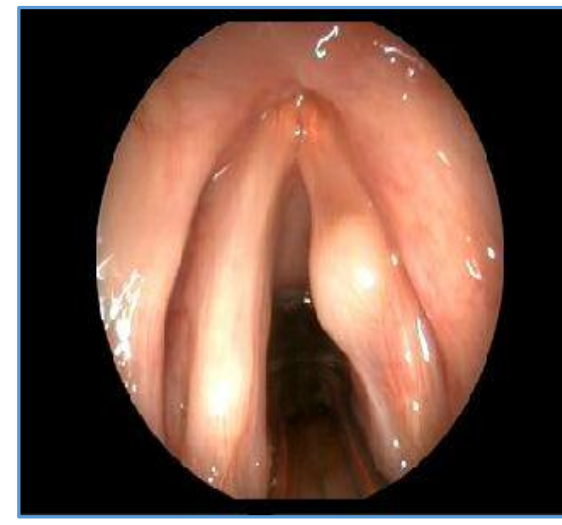

Vocal Cord Cyst

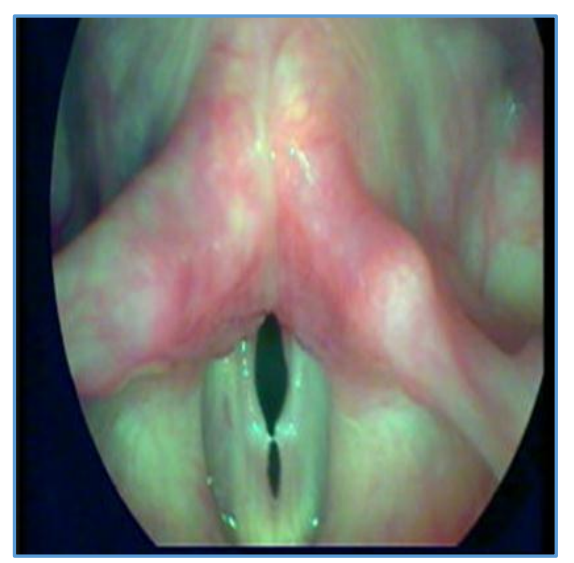

Vocal Cord Nodule

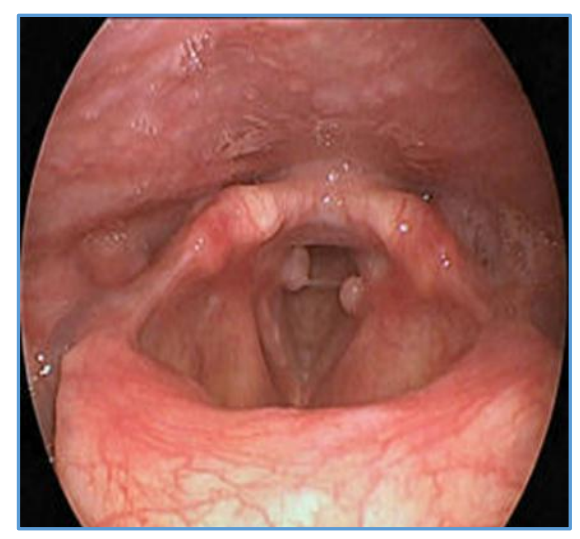

Intubation Granuloma

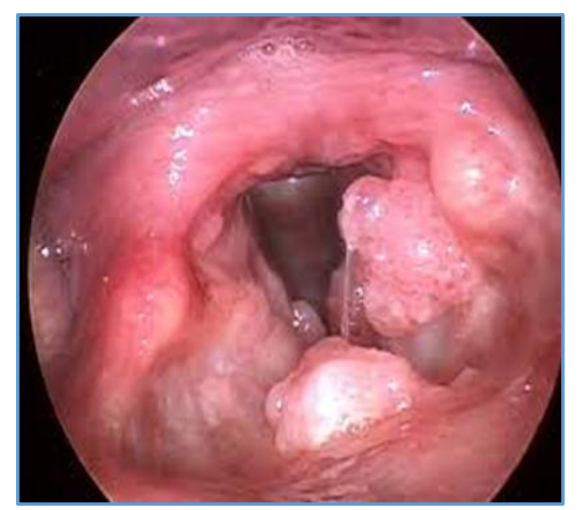

Laryngeal Papilloma 


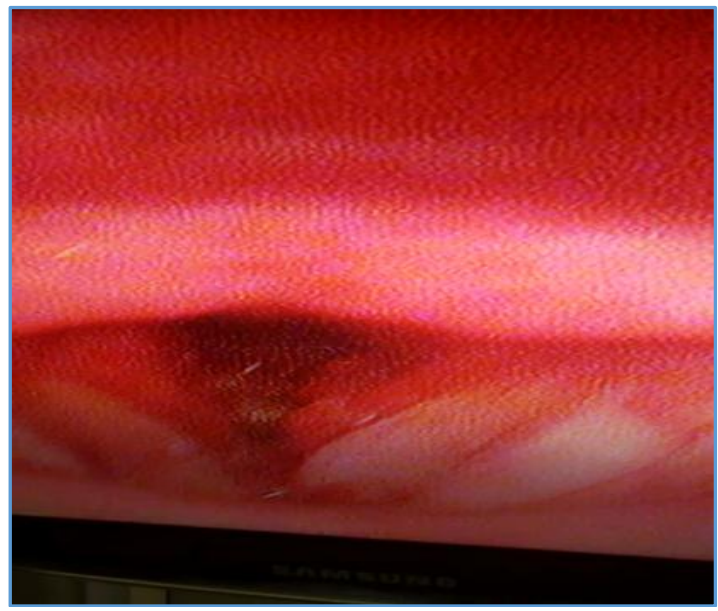

Laryngeal Tuberculosis

\section{Histopathological Examination} Vocal Cord Polyp

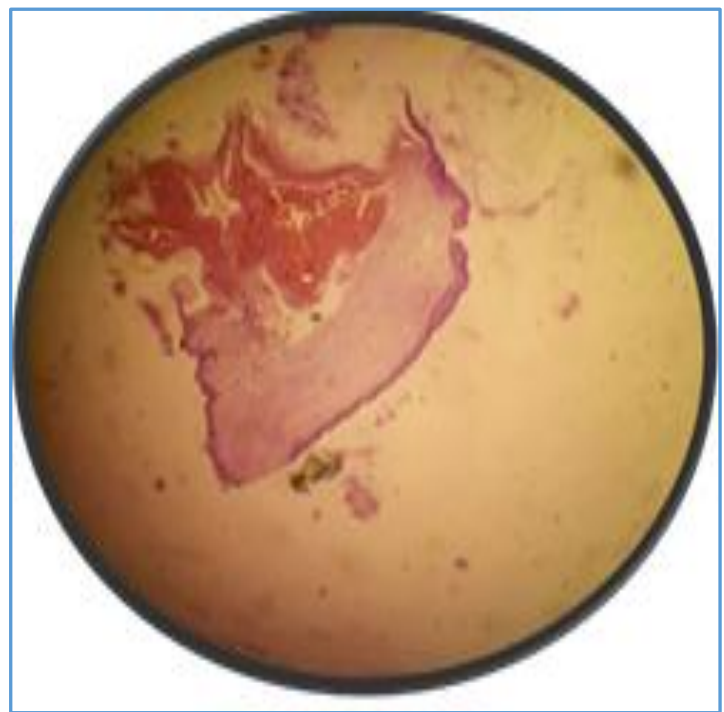

Vocal Cord Nodule

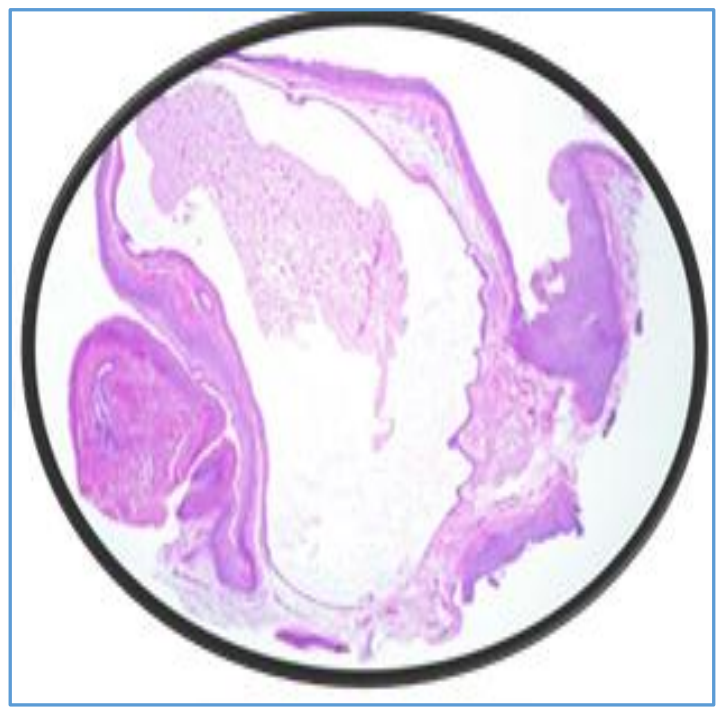

Vocal Cord Cyst

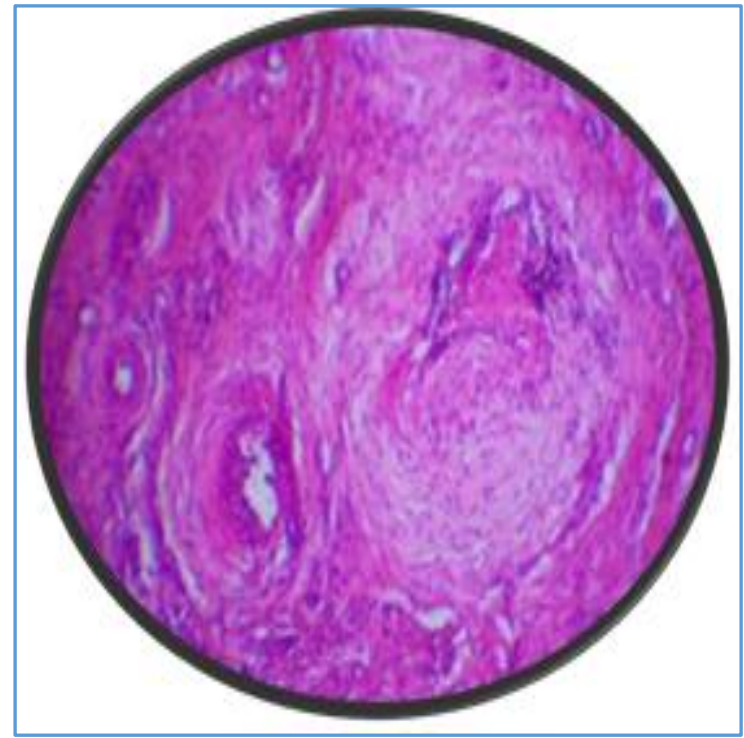

Intubation Granuloma

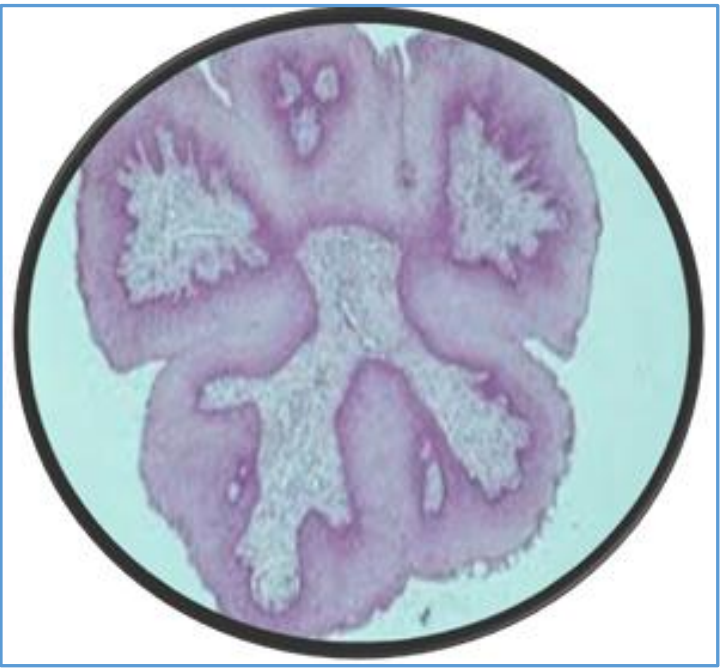

Larynx Papilloma

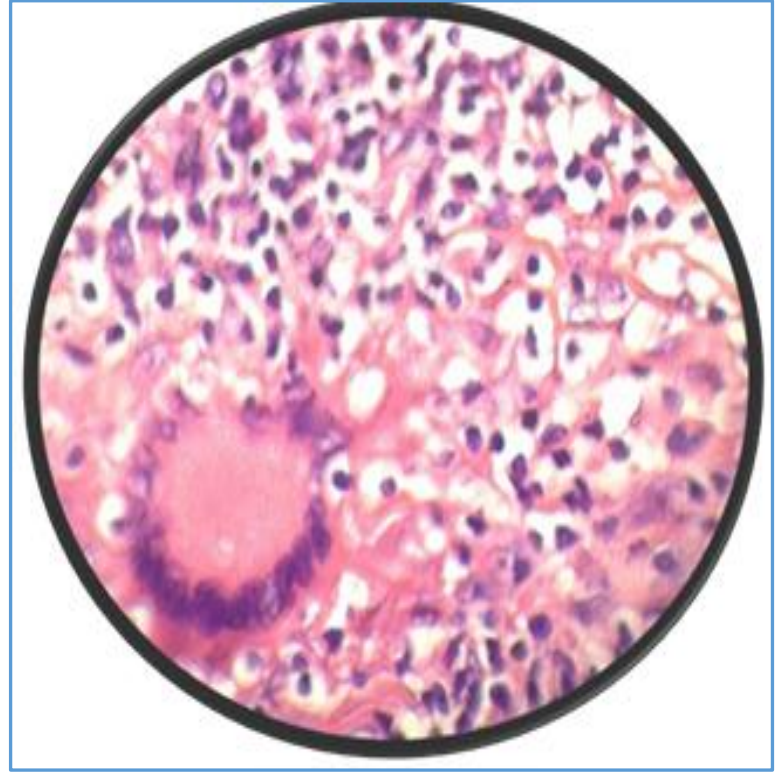

Laryngeal Tuberculosis 


\section{DISCUSSION}

Out of the 54,700 patients seen in the ENT Outpatient Department from November 2013 to November 2015, 40 cases were clinically diagnosed as having benign lesions of the larynx. Thus, the incidence of benign lesions of larynx found in this was $0.073 \%$ or 7 per 10,000 new patients seen. The reported average incidence of these lesions in the literature varies from 6 to 79.8 cases per year. The apparent increase in the incidence of benign lesions may be due to better awareness and concern on the part of patients regarding a change in their voice and better diagnostic facilities available. With increasing stress in day-to-day life, raising level of pollution and changing habits and lifestyles, hoarseness and voice disorders per se are becoming more and more prevalent.

\section{Age and Sex Distribution}

A total of 40 patients with benign lesions of larynx are taken in the present study.

In our study, age of these patients ranged from 5 to 65 years and youngest being 11 years and oldest is 62 years. The majority of patients in our study lie in the age group of 31 to 40 years. A total of 16 patients which is $40 \%$ total patients, which is consistent with study of Chopra $\mathrm{H}$ et al (1997). ${ }^{6}$

In our study, both sexes were included. Out of 40 patients 27 patients were male which was $67.5 \%$ and 13 patients were female which was $32.5 \%$. Male predominance was clearly seen over females, which is consistent with other studies by Chopra $\mathrm{H}$ et al (1997). ${ }^{6}$

\section{Chief Complaints}

In our study among benign lesions of larynx, commonest symptom was hoarseness of voice/ change in voice $(100 \%)$ followed by vocal fatigue (65\%), painful voice production, irritation in throat, difficulty in swallowing, foreign body sensation and breathlessness (both 7.14\% each).

In a study by Pawan Singhal et al (2009), ${ }^{7}$ hoarseness of voice was observed in $100 \%$ cases followed by vocal fatigue in $52 \%$ of the patients, irritation in nearly $22 \%$, cold/ upper respiratory tract infection in $25 \%$ and foreign body sensation in $8 \%$ cases. All these among benign laryngeal masses.

In another study on benign lesions of larynx by Pankaj Kumar Doloi et al (2011), 8 hoarseness was the commonest symptom (95\%) followed by vocal fatigue (52.5\%), cough (30\%), dyspnoea (10\%) and foreign body sensation (7.5\%).

\section{Occupation}

Out of the 40 benign laryngeal masses, majority of patients i.e. 5 cases $(21.42 \%)$ belonged to teacher's class and the least i.e. 1 case (1\%) were in others (watchman, nurse, engineer). Among males, teachers was the commonest occupation i.e. 5 cases $(27.27 \%)$ and majority of the females were housewives i.e. 7 cases $(66.66 \%)$.

In a study by Pawan Singhal et al (2009), 7 majority of patients were housewives followed by teacher's class among benign laryngeal lesions. In a study on laryngeal malignancies by Zeba Ahmed et al, 10 majority of patients were labourers.

\section{Residence}

In our study, majority of patients i.e. 28 cases (70\%) were from urban area and minimum cases i.e. 12 cases $(30 \%)$ were from rural area. In study by Zeba Ahmed et al (2009) ${ }^{9}$ on laryngeal lesions, most of the patients were predominantly from urban areas.

\section{Diagnosis}

The commonest site of origin of lesions was from true vocal cords. Nearly $100 \%$ of lesions were from true vocal cords, the lesions being located in either right vocal cord or the left vocal cord in $70 \%$ of cases and on both vocal cords in $30 \%$ of cases. There was slight a preponderance of the lesions on the right cord 19 cases (47.5\%).

A study by Saudi S et al (2013) ${ }^{10}$ had found same observations as above among benign laryngeal lesions.

After Clinical and IDL, VDL and Microlaryngoscopic examination, we found that vocal polyps and vocal nodules which together constituted $67.5 \%$ of cases were found at the junction of anterior $1 / 3 \mathrm{rd}$ and posterior $2 / 3 \mathrm{rd}$ of the true vocal cords. This is because the mechanical force of vibration is most intense at this site.

In our study of benign lesions of larynx, vocal cord polyps are the commonest 18 cases (40\%). This is in accordance with Dikkers et al (1995) ${ }^{11}$

Kambic et al (1981) ${ }^{12}$ had an incidence of $68.3 \%$, while in study carried by Mangal Singh et al found incidence of $40.7 \%$ (33 cases). However, Chopra et al (1997) ${ }^{6}$ had an incidence of $16 \%$ only.

Among various other types of benign lesions of larynx in our study had found vocal nodules $22.5 \%$, vocal cord cyst (20\%), 2 cases of intubation granuloma (5\%) and 2 (5\%) cases of vocal cord papilloma.

In study by Pankaj Kumar Doloi et al $(2011)^{8}$ most common benign laryngeal lesion noted was vocal polyp (37.5\%) followed by vocal fold nodule $(27.5 \%)$, multiple laryngeal papillomatosis (10\%), Haemangioma (10\%), epiglottic cyst (5\%), vocal cord cyst $(7.5 \%)$ and intubation granuloma $(2.5 \%)$.

In our series we had found 1 case of laryngeal tuberculosis, which was secondary to pulmonary tuberculosis. The main site of involvement were true vocal cord.

The Mahesh Hegade et al (2005)13 had 6 cases of tuberculosis of larynx, of which 5 were secondary to pulmonary tuberculosis.

\section{Treatment}

Surgical treatment was the treatment of choice in the majority of cases studied (100\%) and followed by voice rest and voice therapy. Of the different modes of management mentioned in the literature viz. medical, physical, immunological and surgical, the last one remains the standard treatment of choice in all types of benign tumours and in all age groups.

In our study, microlaryngoscopic excisional surgery of the lesion was done in 40 cases (100\%), Postoperative vocal rest and speech therapy was advised to the patients to prevent recurrence.

We had 2 cases with laryngeal papilloma, in which excision was done under general anaesthesia. In laryngeal TB case, anti-TB drug treatment along with excisional biopsy was done. 


\section{Histopathology}

In our study after histopathological examination, out of 40 cases 18 (45\%) were vocal fold polyps, 9 (22.5\%) were vocal fold nodules, $8(20 \%)$ were vocal cord cyst, laryngeal papilloma 2 (5\%), Intubation granuloma $2(5 \%)$, laryngeal TB $1(2.5 \%)$.

In our study clinical diagnosis was $100 \%$ correct in diagnosing vocal polyp, vocal nodule, vocal cord cyst, laryngeal papilloma, intubation granuloma and laryngeal TB. We had 18 cases clinically diagnosed as vocal fold polyp, which on histopathology revealed 10 angiomatous polyp and 8 cases to be inflammatory polyp.

In a study by Nupur Nerurkar and Sunil Garg (2011) ${ }^{14}$ on correlation between rigid laryngoscopy and histopathology of laryngeal lesions at their voice clinic in Mumbai, their clinical diagnosis was $10.0 \%$ accurate in vocal fold subepithelial cyst, vocal fold nodule, laryngeal papilloma and ulcer.

\section{Post-Operative Follow-Up}

Post-operative management included complete voice rest 2 weeks followed by gradual resumption of voice in order to resume the normal function of the vocal cords.

In our study, majority of patients (92.5\%) are totally symptom free after surgery and $7.5 \%$ have partial recovery of their symptoms.

2 cases (5\%) of laryngeal papilloma and 1 case of laryngeal TB (2.5\%) were partially symptom free after surgery.

The recurrence was in 2 cases of vocal cord papilloma and 1 case of laryngeal TB because of non-compliance of patients.

In study carried by Suliman Saudi et al (2013),10 majority of patients (90\%) were totally symptom free after surgery and $10 \%$ had partial recovery of their symptoms.

\section{CONCLUSION}

1. Benign lesions of the larynx are uncommonly occurring lesions.

2. Non-neoplastic benign lesions are far more common than neoplastic lesions. Males are affected more than females and most common age group involved is $30-40$ yrs.

3. Vocal cord polyps and nodules are the most frequent benign lesions. Lesions like papilloma, intubation granuloma and tuberculosis occur very rarely.

4. Vocal abuse either occupational or habitual is a dominant precipitating factor in the causation of common benign lesions, whereas poor vocal hygiene, addictions like smoking, tobacco chewing and alcohol also plays a significant role in the aetiopathogenesis of these lesions.

5. Hoarseness is the commonest mode of presentation. However, in many cases it may be associated with vocal fatigue.

6. The gold standard for diagnosis of these lesions is careful history, examination by indirect laryngoscopy and videolaryngoscopy followed by microlaryngeal surgical resection and material subjected to histopathology.

7. Microlaryngeal surgery is the treatment of choice in these lesions and postoperative speech therapy should be provided to all the patients to prevent recurrences.

8. Finally, there is a need to educate the general public and especially health care providers to promptly refer patients with hoarseness of voice of more than 2 weeks duration for direct laryngoscopy and biopsy by an otolaryngologist.

\section{REFERENCES}

[1] Pradhan S. Voice conservative surgery in laryngeal cancer. $1^{\text {st }}$ edn. Lloyds Publishing House, 1997:pp 1.

[2] Kerr AG, Hibbert J. Scott Brown's otolaryngology. $6^{\text {th }}$ edn. Butterworth-Heinemann, 1997;5:1-25.

[3] Gerald M. Otolaryngology. Revised edn. LippincotRaven, 1996;3:1-25.

[4] Batra K, Motwani G, Sagar PC. Functional voice disorders and their occurrence in 100 patients of hoarseness as seen on fibre-optic laryngoscopy. Indian J Otolaryngol Head Neck Surg 2004;56(2):91-5.

[5] Garett CG, Ossof RH. Hoarseness. Medical Clinics of North America 1999;83:115-23.

[6] Chopra H, Kapoor M. Study of benign glottic lesions undergoing microlaryngeal surgery. Indian J Otolaryngol Head Neck Surg 1997;49(3):276-9.

[7] Singhal P, Bhandari A, Chouhan M, et al. Benign tumours of larynx: a clinical study of 50 cases. Ind J Otolaryngol Head Neck Surg 2009;61(Suppl 1):26-30.

[8] Doloi PK, Khanna S. A study of management of benign lesions of the larynx. International Journal of Phonosurgery and Laryngology 2011;1(2):61-4.

[9] Ahmed Z, Mutiullah S, Memon M, et al. A clinico pathological study of laryngeal malignancies-an institutional experience. JLUHMS 2009;8(3):214-8.

[10] Saudi S. Benign lesions of the vocal cords in different ages: prospective study of 60 cases. Journal of Medical Science and Technology 2013;2(3):130-4.

[11] Dikkers FG, Nikkels PG. Benign lesions of the vocal folds: histopathology and phonotrauma. Ann Otol Rhinol Laryngol 1995;104(9 Pt 1):698-703.

[12] Kambic V, Radsel Z, Zargi M, et al. Vocal cord polyps: incidence, histology and pathogenesis. J Laryngol Otol 1981;95(6):609-18.

[13] Hegde MC, Kamath PM, Bhojwani K, et al. Benign lesions of the larynx-a clinical study. IJLO 2005;57(1):35-8.

[14] Nerurkar NK, Garg S. Correlation between rigid laryngoscopy and histopathology of laryngeal lesions at our voice clinic. International Journal of Phonosurgery and Laryngology 2011;1(1):29-31. 